\title{
Spontaneous bilateral quadriceps tendon rupture in a patient with renal failure
}

\author{
Varaprasad Naga Vemuri, ${ }^{1}$ Manchikanti Venkatesh, ${ }^{2}$ Venkataramana Kada, ${ }^{3}$ \\ Sunitha Vellathussery Chakkalakkoombil ${ }^{4}$
}

\begin{abstract}
'Department of Radio Diagnosis, NRI Medical College, Chinakakani, India

${ }^{2}$ Department of Radio Diagnosis, Sri Venkateshwara Medical College Hospital and Research Centre, Pondicherry, India ${ }^{3}$ Konaseema Institute of Medical Sciences and Research Foundation Hospital, Amalapuram, India

${ }^{4}$ Department of Radio Diagnosis, Jawaharlal Institute of Post Graduate Medical Education, Pondicherry, India
\end{abstract}

\section{Correspondence to} Dr Sunitha

Vellathussery Chakkalakkoombil, drsunithapnair@rediffmail.com

Accepted 3 February 2018
(A) Check for updates

\begin{tabular}{|l|}
\hline To cite: Vemuri VN, \\
Venkatesh M, Kada V, et al. \\
BMJ Case Rep Published \\
Online First: [please \\
include Day Month Year]. \\
doi:10.1136/bcr-2017- \\
223191 \\
\hline
\end{tabular}

\section{DESCRIPTION}

A 45-year-old man with history of chronic renal failure had sudden onset of severe pain in both his knees following which he was unable to walk and had severe pain in both lower thighs and knee joints. On examination he was pale looking and asthenic. Local examination revealed swelling of bilateral knee joints with restricted extension of knee joints. On palpation small defect was noted in the suprapatellar region, indicating the discontinuity of quadriceps tendon. MRI of bilateral knee joints was done, revealing patella baja (low-lying patella), moderate-joint effusions and full-thickness defect in quadriceps tendons at site of patellar attachment (figures 1 and 2). The patient did not have any other tendon ruptures at the time of presentation to hospital. Due to poor renal function status, the patient was not fit for surgical repair and was immobilised with long leg cast in extension for 8 weeks followed by crutch walker support and advised for follow-up.

Bilateral quadriceps tendon tear is a very rare clinical entity. In 1949 Steiner and Palmer first reported a case of quadriceps tendon tear in a patient with renal failure. Trivial trauma can rupture bilateral quadriceps in patients with chronic renal failure, systemic lupus erythematosus, gout, diabetes, secondary hyperparathyroidism, pseudogout, alkaptonuria, severe osteomalacia and in patients with

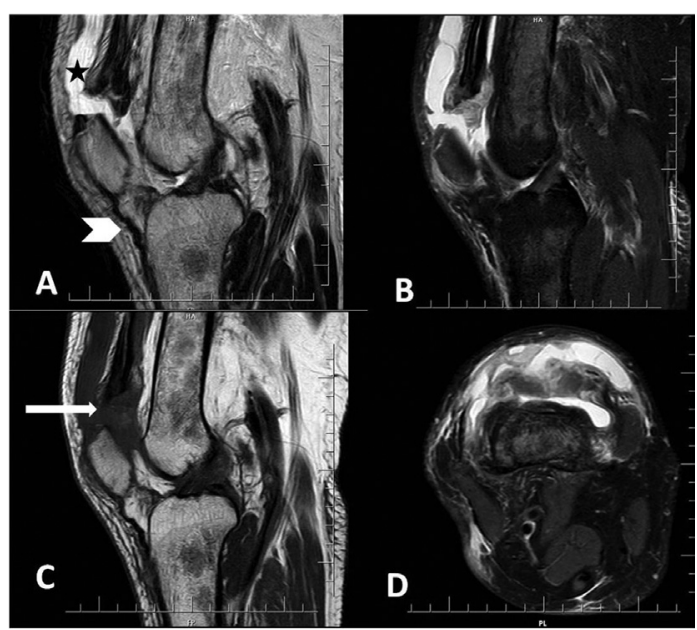

Figure 1 Sagittal T2 (A), sagittal PDFS (B), sagittal T1 (C) and axial PDFS(Proton Density Fat Saturation) (D) MRI of right knee showing full-thickness tear of quadriceps tendon at patellar attachment site (white arrow), wavy patellar tendon (chevron) and moderate suprapatellar joint effusion (star).

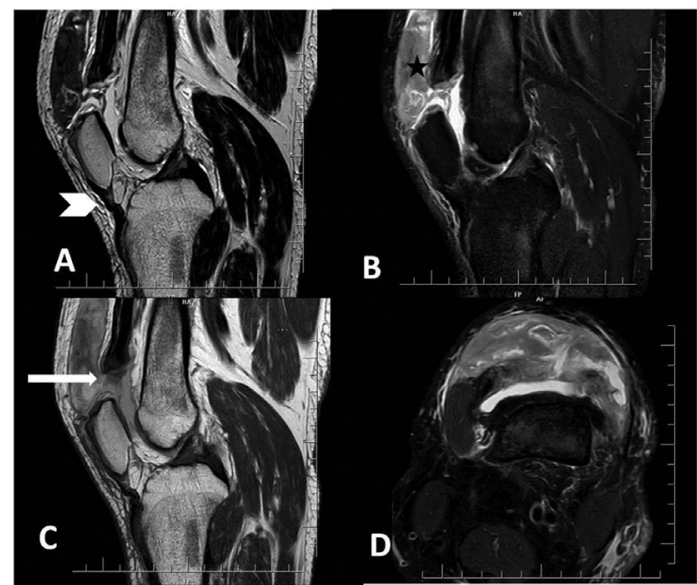

Figure 2 Sagittal T2 (A), sagittal PDFS (B), sagittal T1 (C) and axial PDFS(Proton Density Fat Saturation) (D) MRI of left knee showing full-thickness tear of quadriceps tendon at patellar attachment site (white arrow), wavy patellar tendon (chevron) and moderate suprapatellar hemarthrosis (star).

systemic steroid treatment. The cause of tendon tear has not been well established and various causative factors have been proposed like diminished local circulation, disturbed collagen synthesis, repeated microtrauma and reduced tendon elasticity by calcification. ${ }^{1}$ Diagnosis of quadriceps tendon tear is mainly based on history and clinical examination. Characteristic finding on clinical examination is the suprapatellar gap. Radiographs are not sufficient to make an accurate diagnosis. USG(Ultrasound) is the screening investigation, whereas MRI is essential to assess the extent of rupture, site of rupture, associated osteotendinous injury and preoperative planning. ${ }^{1}$ Erosions of superior pole of patella, calcification within the tendon and patellar enthesophytes are signs of chronic tendinopathy. ${ }^{2}$ Due to the rare incidence of this injury, early clinical diagnosis is essential, which is a challenging task to the physician; one of the clues is the partial defect in the suprapatellar region felt clinically as a small gap. MRI has high sensitivity and specificity with high positive predictive value in diagnosing quadriceps tendon tear compared with USG.

The rarity of bilateral spontaneous quadriceps tendon tear makes the diagnosis difficult. In view of chronic renal disease, the clinician should have high index of suspicion of this entity and early imaging, especially MRI, is essential. Partial tendon ruptures are managed conservatively with physiotherapy, whereas complete ruptures warrant surgical 
intervention. After surgery both knee joints are immobilised usually for 6 weeks followed by gait training with knee braces. ${ }^{3}$

\section{Learning points}

- Bilateral ruptures are very rare and strongly associated with hyperparathyroidism, renal failure, rheumatoid arthritis, gout, obesity, systemic lupus erythematosus, steroid use and diabetes mellitus.

- Common site of rupture is $0-2 \mathrm{~cm}$ from upper pole of patella.

- MRI is the key imaging modality for proper management of quadriceps tendon rupture.

Contributors MV: conception and design, acquisition of data or analysis and interpretation of data. SVC: drafting the article or revising it critically for important intellectual content. VNV: agreement to be accountable for the article and to ensure that all questions regarding the accuracy or integrity of the article are investigated and resolved. VK: final approval of the version published.

Competing interests None declared.

Patient consent Obtained.

Provenance and peer review Not commissioned; externally peer reviewed.

(C) BMJ Publishing Group Ltd (unless otherwise stated in the text of the article) 2018. All rights reserved. No commercial use is permitted unless otherwise expressly granted.

\section{REFERENCES}

1 Wani NA, Malla HA, Kosar T, et al. Bilateral quadriceps tendon rupture as the presenting manifestation of chronic kidney disease. Indian J Nephrol 2011;21:48.

2 Arumilli B, Adeyemo F, Samarji R. Bilateral simultaneous complete quadriceps rupture following chronic symptomatic tendinopathy: a case report. J Med Case Rep 2009;3:9031.

3 Senevirathna S, Radha S, Rajeev A. Bilateral simultaneous rupture of the quadriceps tendon in a patient with psoriasis: a case report and review of the literature. J Med Case Rep 2011;5:331.

Copyright 2018 BMJ Publishing Group. All rights reserved. For permission to reuse any of this content visit

http://group.bmj.com/group/rights-licensing/permissions.

BMJ Case Report Fellows may re-use this article for personal use and teaching without any further permission.

Become a Fellow of BMJ Case Reports today and you can:

- Submit as many cases as you like

- Enjoy fast sympathetic peer review and rapid publication of accepted articles

- Access all the published articles

- Re-use any of the published material for personal use and teaching without further permission

For information on Institutional Fellowships contact consortiasales@bmjgroup.com

Visit casereports.bmj.com for more articles like this and to become a Fellow 